\title{
保存血液の殺菌作用に関する研究
}

\author{
国立予防衛生研究所一般検定部（部長 黑川正身） \\ 斎 藤 晴 一
}

\section{A STUDY ON BACTERICIDAL ACTIVITY OF CITRATED WHOLE BLOOD}

\author{
by \\ Haruichi SaIto (Yamaguchi) \\ The Division of Blood Department of General Biological Control \\ National Institute of Health, Tokyo
}

(Director: Dr.M.Kurokawa)

\begin{abstract}
Purpose of this experiment was to find a quantitative indication for bactericidal activity of citrated whole blood in which was represented at $37^{\circ} \mathrm{C}$. When the experimental materials were removed from the incubator at $37^{\circ} \mathrm{C}$ to it at $4-6^{\circ} \mathrm{C}$, and then cultured, the logarithmic growth curve of surviving bacteria in this materials was parallel to the curve of survival bacteria in bouillon under the same experimental condition. The experiments showed that the logarithmic growth curve of surviving bacteria was regularly constant, and the proportion of the number of bacteria counted in the beginning was almost parallel to the distance of the position between the curves of these bacteria. It was found that the bactericidal activity might be expressed on the number of days (L-Index) from which the distance was calculated by a general arithmetric formula for computing a method of relative potency. The computated standard was found to be a curve of logarithmic surviving bacteria-growth in bouillon. The computated distance was represented by the diference of the positions between the growth curve in materials and in bouillon. The potency of bactericidal activity in test materials could be expressed by the number of L-Index. Studies on the mechanism of bactericidal activity in human stored blood was investigated by this calculating method. The results of this studies pointed out that this
\end{abstract}

method of the expression on bactericidal activity could be used in practice.

\section{目次}

緒 論

実験材料及び実験方法

第 I 部 血液殺菌力の推測及びその表現に関する基 礎的実験

実験 1 殺菌作用の程度と菌增殖曲線との関係

実験 2 血液及びブイヨン中の菌增殖曲線

実験 3 初発菌数と乞の增殖曲線との関係

第 I 部 考察，小括

第II 部 血液殺菌作用の推測一表現方法の有効性に 関する実験

実験 1 . 血液と血墏との殺菌作用について

実験 2.zymosan 並びに加熱処置に上る 血漿の 殺菌力に及活す影響

実験 3 血液並びに血漿の保存による殺菌力の変化 第 II 部 小 括

総括並びに結論

\section{緒論}

近年保存血液の利用が一段と盛んになつてきて いるが，この保存血液の製造上，特に重要視され る問題点の一つとして細菌污染2)8）をあげること ができる。

保存血液の細菌活染の防止策としては, 器其の 
滅菌並びに採血条件を㛜しくして器具の製造及び 採血操作に伴う細菌の混入を防ぎ，更に混入した 細菌に対しては，その登育並びに増殖の抑制を一 つの目的として低温に保存する方法がとられてい る。しかし，所謂グラム陰性好冷菌によつて活染 した保存血液が，しばしば致死的副作用を起し， この菌は低温においてよく発育する点から低温保 存を唯一の，また㵊良の対策であるとする考え 方に疑いをもつ人もある。

最近 Geller 等4)は, 特に低温発育菌による污 染の重要さを説き，保存血液に混入した細菌に対 する一つの対策として, 採血して冷藏する前に血 液を短時間 $37^{\circ} \mathrm{C}$ 保つことによつて，血液の殺菌 作用により污染菌を死滅, 又はをの発育をおくら せることができ，しかも血液の質的変化にはあま り影響をあたえないのでこの方法は有効であると 報告している。

このことから, 実際に㛂染保存血液から分離さ れた低温発育菌 Pseudomonas の1株を用いて 保存血液の殺菌作用について実験してきたが12)13) この研究を進めるための必要性から血液の殺菌作 用に関する基礎的実験として，まず血液殺菌力の 推定一表現方法について検討し, その結果, 合理 的であると考えられる方法を考案することができ たので報告する。

\section{実験材料及び実験方法}

1）菌株：L-5 株 (Pseudomonas の 1 株). 予研, 無菌試験室より分与.

2）保存血液及び血漿：血液として注抗凝固液 B液6) 使用の $\mathrm{O}$ 型人血液を用い, 血嶈はこの保存 血液より遠心分離 (3000 r pm 30 分 $2 \sim 4^{\circ}$ ) して 得たものを使用した。

3）菌液の作製と実験試料への添加：L-5 株 の普通寒天斜面 $25^{\circ}, 24$ 時間培養菌を $0.2 \mathrm{mg} / \mathrm{cc} の$ 割合にブイヨンに接種, $25^{\circ}, 24$ 時間培養し, こ れを生理食塩液で稀釈して, 必要菌量を実験試料 に添加し, 初発菌量を得た。

4）菌数の訫測：菌加試料 $0.1 \mathrm{cc}$ を普通寒天平 板に混稀して $25^{\circ} ， 48$ 時間培養し，その集落数を 算出して菌数を得た。なお 1 試料につき 2 枚の平
板を用いてその平均值をとり試料の菌数とした. 表の菌数は被検試料 $0.1 \mathrm{cc}$ 中の菌数をあらわす。

増殖した試料中の菌数の計測は，10倍連続稀、釈 により，1枚の平板の菌集落数が約 100 コをかぞ える平板の集落数から原試料の菌数を推定した。

5）ブイヨン：普通ブイヨンを用いた。

6) 推計学的分析：直線性の検定は通常直交多 項式の方法7)により, 平行性の検定, 測定值及び

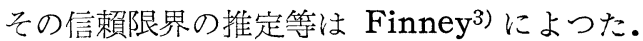

\section{第 1 部 血液殺菌力の推測及びその表現に関す}

\section{る基礎的実験}

血液, 血漿の殺菌力を定量的にあらわす方法と しては, 殺菌力の作用過程の或る時期の生残菌数 を計測し，その減少の程度によつて殺菌力の程度 を表現する方法が最も直接的な方法として考えら れ，実際にもこの方法が使用されているが11)，こ の方法には次の三つの難点がある.

1）被検試料の一部を用いて菌数を計測するに あたり，生残菌数がある程度以下に減少すると菌: 数の測定が不可能になる.

私の当面の研究目的である血液の河染では, 自: 然の状況では多くの場合，混入する菌は多くない と考えられるので，自然に近い状態で実験を行な うためには，この缺点は実験逐行上大きな制約と なる。

2）殺菌作用による菌数減少の速度及びその終 末時点が，被検試料や，管理しがたい実験条件に よつて異つてくるものと考えられるので, 終末菌 数の測定は極めて因難であり，また一定の測定時 点の菌数を比較する場合には計測時点が変ると， 違つた結果が得られる可能性が大きい。

3）殺菌作用による菌数の減少のしかたは直線 的でなく曲線的であるものと考えられるので，何 点かの測定值を求めてそれを平均するという方法 の採用は極めて困難である。

以上のような理由から他の推測並びに表現方法 について検討してみた。

殺菌作用をもつている血液に加えられた菌は, $37^{\circ}$ 下で血液の殺菌作用をうけて著しく減少する が， 4 〜 $6^{\circ}$ に移されると血液の殺菌作用が 発揮 
されなくなり，生残した菌は一定の潜伏期後増殖 を始める。この場合対数増殖期の増殖の割合また はその最大発育菌数（或はその両者）にも血液の 殺菌作用の影響が支ぶものなら，対数増殖期の增 殖の割合即ち対数増殖直線の傾斜または，最大増 殖菌数が血液の殺菌作用の指標となるかもしれ ない。逆にこれらの影響をうけないものであるな ら，対数増殖期の増殖直線の傾斜は，最初に加え られた菌数や，血液の殺菌作用をうけて一度減少 した菌が適当な環境下におかれて増殖しはじめる 時の菌数の大小には関係なく一定であり，したが つて対数増殖期の増殖直線の位置は対数増殖期に 入る時期の違い，即ち䐅退期の大小と一定の関係 があるはずであるから，遲退期の大小を対数増殖 期の増殖直線の位置で表現することができる.

殺菌作用をうけて一度減少した菌数の大小は, それが適当な環境下におかれて増殖に移行する時 期の菌数とほぼ同じであろうと考えられるので， もしもこの遲退期の大小がこれらの菌数と比例す るものなら, 対数増殖期の増殖曲線の位置に上つ て殺菌作用の大小を表現することができるものと 考えられる。

この方法はすべて相対的な関係で殺菌作用の大 小を表現するのであるから当然その相対値のより ぞころとなる標準が必要となる。この標準は比較、 的容易に得られ，しかも再現性のあるものでなけ ればならない。この点でブイヨン等の培地はこの 目的に最も適当するものと老えられる. $4 \sim 6^{\circ}$ 下におけるブイヨン中の菌の増殖曲線の位置が一 定であり；対数増殖淔線の傾斜が血液中における 菌増殖のそれと同一であるならば，ブイヨン中の 菌の対数増殖直線を標準にして，被検試料とブイ ヨン中の菌の増殖直線の位置の差を日数であらわ すことができるものと考える。

上記の問題点について一つ一つ実験的に確か め，次に述べるような結果を得た。

実験 1 殺菌作用の程度と菌増殖曲線との関係 方法

1） $4^{\circ}$ に泠却した保存血液に菌を加えて 短時 間振盪鹠拌し，各12cc宛18本の試験管に分注し
図 1-1 殺菌作用の程度々菌增殖曲線

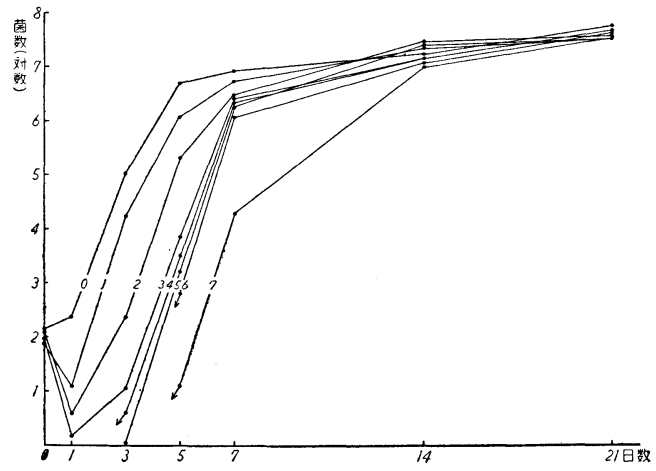

一印はその前回の計測で菌を検出できなかつた事 を示す. 各線の数字は作用時間を示す

図 1-2 殺菌作用の程度と菌増殖曲線

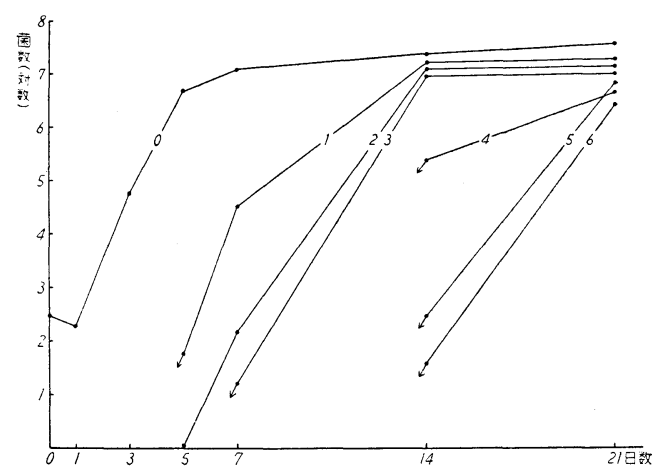

一印はその前回の計測で菌を検出できなかつた事 を示す.各線の数字は作用時間を示す

て, 各試験管毎に初発菌数を計測すると同時に $37^{\circ}$ 恒温槽に入れる。なお 18 本中 2 本の血液は恒温槽 に入れないで, 初発菌数の計測後直ちに $4 \sim 6^{\circ}$ の 冷藏庫に移す。

2）恒温槽に入れた血液は， 2 本を 1 組として 1 時間毎にとりだし直ちに菌数を計測する。

3）加温終了後の菌数計測を終つた血液は 4 〜 $6^{\circ}$ の冷藏庫に移して培養し, 図 1-1，2の上 うに日を追つてその菌数を計測して増殖曲線をと つた。

4）対照実験としてブイヨンを用いて血液と同 様の実験を行つた。

成績

$37^{\circ}$ 作用直後に菌を検出できなかつた血液で 
も，何日か後には菌を検出できた例が多かつた。 この菌の検出され始める 時期は $37^{\circ}$ の作用時間を ながくうけたほどおくれている。

一方，血液が $4 \sim 6{ }^{\circ} に$ 移されてからの生残菌 の増殖が対数増殖期に入つてからの菌撸殖の割合 は一定である可能性が考えられ，またその最大増 殖菌数はいずれも同じ值を示しているようにみう けられた。

同一実験が 5 lot の血液について行われたがす べて上記と同様の成績であつた。したがつて, 最 大増殖菌数や, 対数増殖直線の傾斜を殺菌力の表 現とする可能性は否定される。

ブイヨン及び加温しないで 4 〜 $6^{\circ}$ においた血 液中の菌の消長も, 䐅退期に差はあるが, その対 数増殖期の増殖の割合は, 加温した血液と大差な いものとみてもよいとおもわれる成績であつた。

即ち以上の成績は $4 \sim 6^{\circ}$ での対数増殖期の菌 の増殖の速度は $37^{\circ}$ の加温の有無及び血液, ブイ ヨンの區別なくいずれも同様であることを示唆し ているとおもわれた。

実験 2 血液及びブイヨン中の菌増殖曲線. 次に対数増殖期の菌増殖の速度について更に詳 しい実験を行つた。

\section{方法}

1） $4^{\circ}$ に冷却した保存血液及びブイヨンに菌 を加えて短時間振璗攪拌後, 血液は 8 本, ブイ ヨンは 4 本の試験管に分注して初発菌数を計測す る。

2) 直に血液の試験管 4 本は $4 \sim 6^{\circ}$ に, 残り の 4 本はブイヨンと共に $37^{\circ}$ 恒温槽に入れて 6 時 間作用させ, 加温直後の菌数を計測してから 4 $6^{\circ}$ に移し，以後 24 時間毎に菌数を計測してその 増殖曲線をとつた。

$37^{\circ}$ の作用時間を 6 時間とした理由は, 実験 1 の成績から，生残菌数はできるだけ少ないが菌が 完全には殺されないとおもわれる最もながい作用 時間としてえらんだものである。

成績

得られた成績は推計学的に検討した結果, 対 数堌殖期における各増殖曲線がほほほ直線であるこ
図 $237^{\circ} \mathrm{C}, 6$ 時間加温血液, ブィヨン並びに非加 温血液中の菌増殖曲線

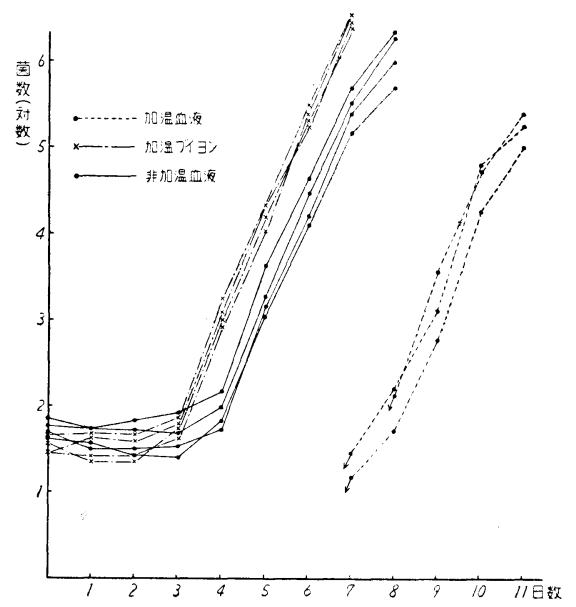

＼cjkstart印はその前日の計測で菌を検出できなかつた事 を示す.

と，お互に平行していることを確かめることがで きた (図 2 ).

即ち，血液の殺菌作用をうけた生残菌及び殺菌 作用をうけない血液中の菌の対数増殖期における 菌増殖の㓶合はほほ同一であると考えられ，した がつて菌の増殖が対数増殖期に大つてからは，血 液の殺菌作用の影響を殆んどうけないと考えてよ いことが実証されたわ就である。

また $37^{\circ}$ の作用をうけたブイヨン中の菌の増殖 直線が, 加温血液, 不び非加温血液での対数増殖 直線と平行していることから，はじめに述べた殺 菌力測定の標準としてブイヨンを用いることが可 能であると考えられる。

実験 3 初発菌数とその増殖曲線との関係 方法

$4^{\circ}$ に泠却した保存血液 $0.1 \mathrm{cc}$ に対し, 菌数を 10 コ， 3 コ，1コ，0.3コ，0.1コの割合になる ように加え，加温することなく $4 \sim 6^{\circ}$ に培養， 24時間毎に菌数を計測してその増殖曲線を求め た。なお同一条件のものについて常に 2 本あて実 験した。

成績

これまでの実験と同椂, 対数増殖期の各増殖曲 線がほほ直線であり，且平行であることがたしか 
図 $34 \sim 6{ }^{\circ} \mathrm{C}$ 血液中の菌増殖曲線 Lot. 2218
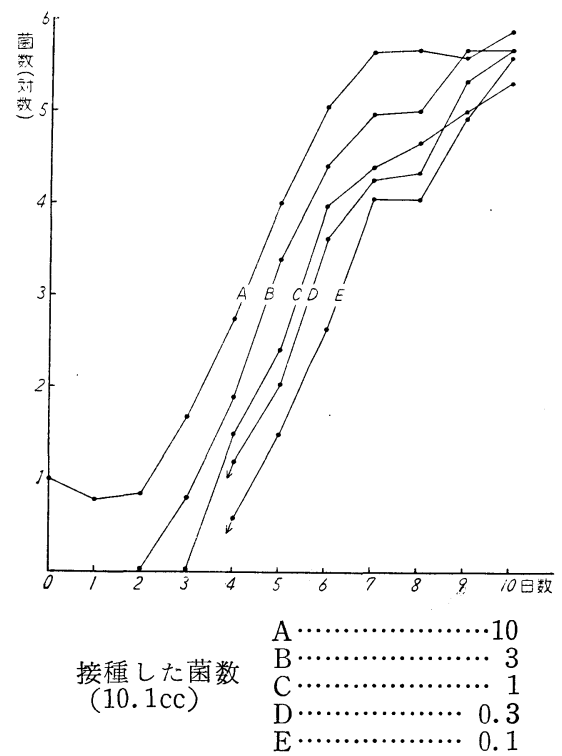

一印はその前日の計測で菌を检出できなかつた事 を示す。

図 4 対数增殖期における各種線間の間隔の同一性

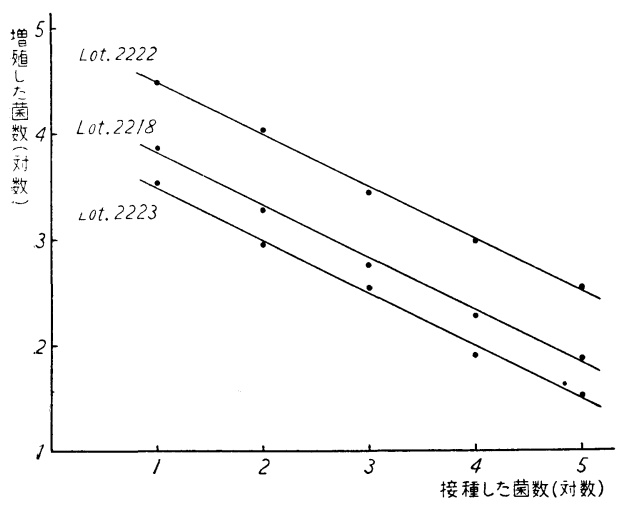

められたので（図 3 ), 次に各増殖直線上の 4 日 目，5日目， 6 日目の菌数（対数）の平均值を求 めて最初の接種菌量（対数）に対してプロツトす ると両者に直線関係が証められた（図 4 ). 別に3 lot の血液を用いて実験を繰返したが，結果は全 く同じであつた。このことは一定比に加えられた 菌数と, 対数増殖期に拈ける一定日の菌数とが比 例していることを示すものであり，また，初発菌 数の割合が一定であるならば各対数増殖直線間の 間隔（ $\mathrm{x}$ 軸）がほぼ同一であることを意味してい
る、したがつて対数増殖直線の位置によつて初発 菌数の大小の割合を間接的に表現できるものと考 える。

考察

$37^{\circ}$ におかれて一定の血液の殺菌作用をうけて 減少した菌数は，この血液が $4 \sim 6^{\circ}$ に移されて から，その生残菌が増殖しはじめる時の菌数と同 一であるか否かはまだかならずしも明らかでない が，少くともこの両者汢比例するものと考えてさ しつかえないものとおもわれる。したがつて上記 の実験結果から, 対数増殖直線の位置によつて血 液の殺菌作用の大小，または殺菌作用の効果の大 小を相対的に表現して大きなあやまりはないもの と考えられる。

ブイヨンでの対数増殖直線の位置を標準とし て, 被㭘血液の対数増殖直線との位置の差を日数 ( $\mathrm{x}$ 軸) であらわすには次に示す相対力価 (M) の一般式3)を用いて計算することができる。

$$
\mathrm{M}=\overline{\mathrm{x}}_{\mathrm{S}}-\overline{\mathrm{x}}_{\mathrm{T}}-\frac{\overline{\mathrm{y}}_{\mathrm{S}}-\overline{\mathrm{y}}_{\mathrm{T}}}{\overline{\mathrm{b}}}
$$

$\overline{\mathrm{x}} \mathrm{s}=$ ブイヨンでの対数増殖期の $3 \sim 4$ 点の日数 の総加平均 $=\frac{\Sigma \mathbf{x}_{\mathrm{T}}}{\mathrm{N}}$

$$
\overline{\mathrm{x}}_{\mathrm{T}}=\text { 同上 (被検試料) }=\frac{\Sigma \mathrm{x}_{\mathrm{T}}}{\mathrm{N}}
$$

$\overline{\mathrm{y}}_{\mathrm{S}}=$ ブイヨンでの対数増殖期の $3 \sim 4$ 点の菌数 (対数) の総和平均 $=\frac{\Sigma_{\mathrm{y}_{\mathrm{T}}}}{\mathrm{N}}$

$$
\overline{\mathrm{y}}_{\mathrm{T}}=\text { 同上 (被検試料) }=\frac{\Sigma \mathrm{y}_{\mathrm{T}}}{\mathrm{N}}
$$

$\overline{\mathrm{b}}=$ 共通の回帰係数

$$
\overline{\mathrm{b}}=\frac{\operatorname{Sxy}\left(\mathrm{T}_{1}\right)+\operatorname{Sxy}\left(\mathrm{T}_{2}\right)+\cdots+\operatorname{Sxy}(\mathrm{s})}{\operatorname{Sxx}\left(\mathrm{T}_{1}\right)+\operatorname{Sxx}\left(\mathrm{T}_{2}\right)+\cdots+\operatorname{Sxx}(\mathrm{S})} \cdots
$$

$\left.\left(\mathrm{T}_{1}\right), （ \mathrm{~T}_{2}\right) \cdots$ 各被検体，（S） は標準（ブイ ヨン)をあらわす。

$$
\begin{aligned}
& \mathrm{Sxx}=\Sigma \mathrm{x}^{2}-\frac{\left(\Sigma_{\mathrm{x}}\right)^{2}}{\mathrm{~N}} . \\
& \mathrm{Sxy}=\Sigma \mathrm{xy}-\frac{\Sigma_{\mathrm{x}} \Sigma_{\mathrm{y}}}{\mathrm{N}}
\end{aligned}
$$

$\mathrm{Sxx}$ 及び Sxy を各試料每に計算した後（6） によつて るを計算する。

実験 3 の血液 3 lot を用いて行つた実験成績を もとにして30本の対数増殖直線より求めた共通の 


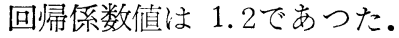

計算によつて得られた $\mathrm{M} は ，$ 被検血液中の菌の 対数増殖直線がブイヨンでの対数増殖直線の位置 から何日はなれているかをあらわしているもので あつて，い>かえれば，ブイヨンでの遲退期を基 準にして、これと被検血液での遲退期との差をあ らわしたものであるから，得られたMの值を lag phase（遲退期）の工をとつて便宜上L指数とよ ぶことにする。

ブイヨンと被検血液との対数増殖直線の位置の 差は，血液により殺菌された菌数の程度に関係す るから，殺菌力の強い血液での対数増殖直線汪ど ブイヨンでの対数増殖直線からその位置がはなれ ることになる。したがつて几指数は大きくなる。 このL指数の示す意味を別な角度から表現する と $37^{\circ}$ で血液の殺菌作用をうけて一度減少した菌 が，一定の菌数に増殖するまで何日か>るかとい うことをあらわしているものといえる。

この測定方法を用いて血液の殺菌力を表現する にあたつては次の点に注意しなければならない。

1）毎回の実験条件をできる限り一定にする.

2） 1 回の実験毎にブイヨンを対照にとり，各 実験毎のブイヨンでの対数増殖直線の位置及び回 㴆係数の変化に注意する。

3）ブイヨン及び被検血液の対数増殖期におけ る増殖直線の平行性及びその共通の回帰係数を計 算してそれらの変化に注意する。

実験詥差については計測による誤差, 即ち 2 枚 の平板を用いての計測誤差を計算した結果，Mの 信賴限界（95\%）は土0.2であつた。しかしなが ら, 実験による詥差の要因はこのほかにも次の場 合が考えられる。

1）実験に用いる種培養のちがい.

2）低温培養に移してからの温度の変動による 菌の増殖速度の变化.

3）菌数計測時の稀釈操作.

4）その他，実験上一定できない実験条件.

註: 第 1 部, 実験 1 の結果から,この初発菌数及び $37^{\circ}$ での作用の関係が適当とおもわれる。
小括

血液殺菌力の新らしい推測一表現方法について 実験検討した結果, 殺菌作用後の試料を $4 \sim 6^{\circ}$ に培養して，生残菌の堌殖曲線をとり，その対数 増殖期での増殖直線の位置と標準として同時に培 養したブイヨンでの対数増殖直線の位置との差を 相対力価の一般式によつて計算してこれを日数で あらわし，殺菌作用の力価を定量的に表現する方 法が可能であることがわかつた。

この方法は, 従来使用されている殺菌作用によ り減少した菌数を測定して殺菌作用の大小を表現 する方法と比較して合理的であり実験誤差の少な い方法であると考える。

第II部 血液殺菌作用の推測一表現方法の有効 性に関する実験

次に第 I 部で得られた血液の殺菌作用の推測並 びに表現方法の有効性の確認及び保存血液の殺菌 作用に関係する機構の追求を目的として次の実験 を行つた。

実験 1 血液と血嶈との殺菌作用について.

まず血液の殺菌作用の所在が血漿部分にあるか 血球部分にあるかについて検討した。

方法

1）血液，血漿及びブイヨンを $4^{\circ}$ に冷却し て，菌を200〜 500コ/0.1cc（註）の割合に加 え, 振盪攪汼して均一浮遊液として, 各 $10 \mathrm{cc}$ 宛分 注して初発菌数を計測する（同一試料につき 2 本 宛実験した).

2）初発菌数の計測後血液, 血漿及びブイヨン は直ちに $37^{\circ}$ 恒温槽で 2 時間加温（註）した後 4 〜 $6^{\circ}$ の冷藏庫に移して培養する.

3） $4 \sim 6^{\circ}$ に移してからは 24 時間毎に試料中 の菌数を訓測して各試料毎に増殖曲線をとる。菌 数の計測は菌の増殖が対数増殖期をすぎるまで継 続する。

4）以上の実験で得られた数值から L指数を求 めた。

成績

血液及び血漿は同一 1otのものを用い，その殺 菌力を同時に実験して比較した。 
表 1 血液，血漿の L 指数

\begin{tabular}{|c|c|c|c|c|}
\hline Lot & & 1 & 2 & 平 均 \\
\hline \multirow{2}{*}{7713} & 血液 & 3.65 & 3.70 & 3.675 \\
\hline & 血獎 & 3. 82 & 2.98 & 3.400 \\
\hline \multirow{2}{*}{9393} & 血液 & 4. 12 & 4.85 & 4.485 \\
\hline & 血獎 & 4.64 & 4. 66 & 4.650 \\
\hline
\end{tabular}

得られたL指数をみると両者の差は実験誤差の 範囲内にある（表 1 ）.

このことから血液と血漿の殺菌力にはあまり違 いがないものと招もわれ，血液の殺菌作用は主 に血漿部分にあると考えてもよいものと考えられ る、したがつて， $37^{\circ}$ で発揮される新鮮保存血液 の殺菌作用については，同一 $10 t$ の血液から得ら れた新鮮血漿についてしらべた実験成績をもつて 判断しても大きな愦まりはないものと考える。

実験 2 zymosan ${ }^{10)}$ 処置, 並びに加熱処置に よる血嶈の殺菌力に及涩す影響

殺菌作用の本態が血漿中に存在するものと考 え，血漿の殺菌作用は properdin system ${ }^{155) 9}$ ) 10)11によるものではなかろうかと推定し次の実験 を行つた。

材料

1) zymosan 浮游液の作り方 ${ }^{11)}$ :(Fleischman Lab., Lot 9 B 551 Typ A 及び Nutritional Biochemicals Co., Lot 7943)

パルビタール 緩衝液10) で $50 \mathrm{mg} / \mathrm{cc}$ の zymosan 浮游液を作り，これを熱湯中で 1 時間煮沸し， 4000rpm 30分間遠心分離して上清をすて， 前記 パルビタール 緩衝液で原量にもどして再浮游さ せ， $1 \sim 0^{\circ}$ に保存する。使用時に無菌的に乳錸 で磨砕して実験に使用した。

2）zymosan 処置血漿：血漿 $0.9 c c$ 刘し上 記 zymosan 浮游液を $0.1 \mathrm{cc}$ の割合に加えて $37^{\circ}$ 恒温槽で 15 分毎に振盪攪挥しながら 1 時間加温 し, 加温終了後 $4000 \mathrm{rpm} 30$ 分間 $\left(2 \sim 4^{\circ}\right)$ 遠心 分離して zymosan を除き，上清を zymosan 処置血漿とした。

3）加熱血漿：56 の恒温槽で30分間加熱処置 した血漿.

方法
同一 lot の血漿を 3 分し, zymosan 加熱の各 処置血漿と無処置血漿の 3 種の血漿についてその 殺菌力を測定した（実験手技は第 II 部，実験 I と 同じ)。但し無処置血漿は zymosan 処置血漿と 実験条件を揃えるために $37^{\circ} ， 1$ 時間加温して後 実験に用いた。

以上の実験を 5 lot の血漿についてしらべた。 成績

表 2 に示す如く，各血漿の L指数は無処置血漿 が一番大きく, zymosan 処置血漿, 加熱血漿の, 順に減つている．また各実験毎に無処置血漿の開 きが最も大きく, zymosan 処置血漿の工指数に も相当に開きがみられるが，加熱血漿の工指数は 殆んど $0.8 \sim 1.0$ の間にあつて実験鿁差の範囲内 にある、zymozan 処置血漿のL指数の開きは実 験操作のちがいによつて生じたと考えられる点も

表 2 各処置血獎の L 指数の变化

\begin{tabular}{|c|c|c|c|c|}
\hline Lot & 試験管 & $\begin{array}{l}\text { Zymo- } \\
\text { san }\end{array}$ & 加熱 & 無処置 \\
\hline A & 1 & 1.63 & 0.83 & 3.61 \\
\hline \multirow{2}{*}{ B } & 2 & 1.81 & 0.62 & 3.80 \\
\hline 1 & 0.99 & 0.72 & $\infty$ \\
\hline C & 2 & 0.87 & 0.91 & 4.09 \\
\hline 1 & 2.11 & 0.99 & $\infty$ \\
\hline D & 2 & 2.04 & 0.87 & $\infty$ \\
\hline 1 & 0.90 & 0.93 & 3.03 \\
\hline E & -1 & 0.82 & 0.87 & 2.72 \\
\hline 2 & 1.10 & 0.79 & 3.74 \\
\hline 1.00 & 0.73 & 3.55 \\
\hline
\end{tabular}

×10日後においても菌を検出できなかつたもの

あるが，多くの血漿では無処置血漿のL指数の大 小に比較的平行していることからみると, 各血漿 中に含まれる殺菌作用物質と加えた zymozan と の量的関係が主な原因となつているようにおもわ れる。

zymozan 処置血漿の L指数と無処置血漿の L 指数とを比較すると明らかな差があり，血漿の殺 菌力は zymozan 処置によつて減弱することが. わかつた。

加熱血嶈の L指数が一定の值であることは $37^{\circ}$ で発揮される血液の殺菌作用は $56^{\circ} \mathrm{C} ， 30$ 分加熱に 
よりほ注完に不活化されることを示すものであ ろう（加熱血漿は菌を加えて $37^{\circ}$ に作用させても 菌数の減少は証められなかつた)，Pillemer 等9 は血清中の properdin $は 56^{\circ} ， 30$ 分の加熱処置 により不活化されると述べている。

また，加熱血漿のL指数が一定の值を示してい ること注加熱血漿での遲退期がブイヨンでの逰退 期よりも常に一定してながいことを示しているも のである。これは（1）血漿中にLー5 株の増殖を 抑制する作用があり，56，30分の加熱によつて 不活化されない物質の存在を示すものか，(2) $56^{\circ}$ 加熱により Lー5 株の発育を阻害する物質が生じ たのか，あるいは（3)ブイヨンに培養された菌が 異つた培地に移されたことによる適応等によるも のか，少くとも3つの場合がありうるとおもわれ る。

これらの点についてまず（3）の可能性について 次の実験を行つた。

ブイヨン及び無処置血漿, 加熱血漿に L- 5 株 をうえて $4 \sim 6^{\circ}$ に培養し, 菌の増殖が対数増殖 期に入る時期をえらんで，それぞれの培地で 2 代 継代し，各々をブイヨン及び無処置血漿，加熱血 漿にそれぞれ加え，工指数を測定したが，いづれ の場合も加熱血漿の L指数に差異は認められなか つた，一方無処置血漿の工指数は大体において加 熱血漿よりその值は大きく，小さい場合でも加熱 血漿より小さい例は一例もなかつた。即ち（3）の 可能性は殆んどないとおもわれる。

（2）の可能性については，積極的に否定する材 料も肯定する材料もないが，zymozan 処置によ る L指数の低下の最大值が，加熱血漿の L指数と 活涩一致することからみると，この可能性を考え るために更にいくつかの前提が必要になるとおも われる。

（1）の可能性についても積極的な材料がない が，もしもこのような物質があるものとすると， $56^{\circ} ， 30$ 分の加熱処置によつてL指数が一定の值 まで低下するということから考えて，この「物質 」は各血漿に一様に含まれるものであると考えら れる.また，この「物質」と $56^{\circ}$ 30分で完全に不
活化される作用物質とは温度に対する安定性を異 にするものであり，また加熱血漿々無処置血漿の $37^{\circ}$ 加温直後の菌数の变化に明らかな差があるこ とから，それぞれの作用機序は異るものと考えら れる。

以上のように，加熱血漿中での遲退期がブイヨ ンのそれより一定して大きいことの原因を明確に するにはまだ実験が必要であるが，このような現 象はこの方法を使うことによりはじめて見出され たものである。

zymozan 処置血漿の補体価は無処置血漿に比 較して低下している。この点 Pillemer ${ }^{199) 10)}$ 等 の37\%下で zymozan と properdin が共同し て補体を不活化すると報告していること〉一致す る。

実験 3 血液並びに血漿の保存による殺菌力の 変化

血液と血漿という異つた状態で保存された場合 の， $37^{\circ}$ で発揮される殺菌作用の消長をしること を目的として次の実験を行つた。

方法

同一 1ot の保存血液から，その約 $1 / 2 を$ 用いて血 漿を分離し，全血液の残部及び血漿を同一条件下 で $4 \sim 6^{\circ} に 3$ 週間保存し， 1 週間毎に血液及び 血漿それぞれの殺菌力を測定した（実験手技は第 II 部, 実験 1 と同じ).

血液の殺菌力の推測には殺菌力測定のつど, 保 存した全血液から必要だけの血漿を分離して試験 に供した。

なお殺菌力の推測は，各試料毎に zymozan 処 置及び加熱処置の血漿をつくり，平行して実験し た。また，殺菌力の変化が実験毎の変動でないこ とを確かめるために，毎週 1 lot ずつの血液の推 測を新たに開始し，例えばDの採血直後， Cの保 存 1 週目, $\mathrm{B}$ の保存 2 週目, $\mathrm{A}$ の保存 3 週目の各 血液, 血漿を同時に試験して, お互の比較対照す る方法をとつた。

成績

血液及び血漿の，37でみられる殺菌力は保存 によつて緩徐に，または急速に低下し，その速さ 
表 $34 \sim 6{ }^{\circ} \mathrm{C}$ 保存による血液及び血獎の $\mathrm{L}$ 指数

\begin{tabular}{|c|c|c|c|c|c|c|c|c|c|}
\hline \multirow{2}{*}{ Lot } & \multirow{2}{*}{ 処 置 } & \multirow{2}{*}{ 試験管 } & \multirow{2}{*}{ 採血直後 } & \multicolumn{2}{|c|}{ 1週間保存 } & \multicolumn{2}{|c|}{2 週間保存 } & \multicolumn{2}{|c|}{3 週間保存 } \\
\hline & & & & 血液 & 血漿 & 血液 & 血漿 & 血液 & 血墏 \\
\hline \multirow{3}{*}{ A } & 無処置 & $\begin{array}{l}1 \\
2 \\
\end{array}$ & $\begin{array}{l}3.61 \\
3.80 \\
\end{array}$ & $\begin{array}{l}1.87 \\
2.07 \\
\end{array}$ & $\begin{array}{l}0.83 \\
0.88 \\
\end{array}$ & $\begin{array}{l}1.47 \\
1.44 \\
\end{array}$ & $\begin{array}{l}0.74 \\
0.74 \\
\end{array}$ & $\begin{array}{l}1.25 \\
1.24\end{array}$ & $\begin{array}{l}0.91 \\
0.69 \\
\end{array}$ \\
\hline & 加 熱 & $\begin{array}{l}1 \\
2\end{array}$ & $\begin{array}{l}0.83 \\
0.62\end{array}$ & $\begin{array}{l}0.82 \\
0.72 \\
\end{array}$ & $\begin{array}{l}0.78 \\
0.76\end{array}$ & $\begin{array}{l}0.69 \\
0.74 \\
\end{array}$ & $\begin{array}{l}0.98 \\
0.89\end{array}$ & $\begin{array}{l}0.46 \\
0.56\end{array}$ & $\begin{array}{l}0.67 \\
0.63 \\
\end{array}$ \\
\hline & Zymosan & $\begin{array}{l}1 \\
2 \\
\end{array}$ & $\begin{array}{l}1.63 \\
1.81 \\
\end{array}$ & $\begin{array}{l}1.00 \\
0.80 \\
\end{array}$ & $\begin{array}{l}0.73 \\
0.70 \\
\end{array}$ & $\begin{array}{l}0.76 \\
1.01\end{array}$ & $\begin{array}{l}0.69 \\
0.71 \\
\end{array}$ & $\begin{array}{l}0.88 \\
0.97 \\
\end{array}$ & $\begin{array}{l}0.58 \\
0.58 \\
\end{array}$ \\
\hline \multirow{3}{*}{ B } & 無処置 & $\begin{array}{l}1 \\
2 \\
\end{array}$ & $\begin{array}{c}\infty \\
4.09\end{array}$ & $\begin{array}{c}\infty \\
3.50 \\
\end{array}$ & $\begin{array}{l}3.12 \\
3.22 \\
\end{array}$ & $\begin{array}{c}\infty \\
4.15\end{array}$ & $\begin{array}{c}\infty \\
2.76 \\
\end{array}$ & $\begin{array}{c}\infty \\
5.08\end{array}$ & $\begin{array}{l}1.45 \\
1.46 \\
\end{array}$ \\
\hline & 加 熱 & $\begin{array}{l}1 \\
2 \\
\end{array}$ & $\begin{array}{l}0.72 \\
0.91 \\
\end{array}$ & $\begin{array}{l}0.64 \\
0.70\end{array}$ & $\begin{array}{l}0.70 \\
0.79 \\
\end{array}$ & $\begin{array}{l}0.77 \\
0.81\end{array}$ & $\begin{array}{l}1.03 \\
1.00 \\
\end{array}$ & $\begin{array}{l}0.54 \\
0.50\end{array}$ & $\begin{array}{l}0.63 \\
0.39 \\
\end{array}$ \\
\hline & Zymosan & $\begin{array}{l}1 \\
2\end{array}$ & $\begin{array}{l}0.99 \\
0.87\end{array}$ & $\begin{array}{l}0.74 \\
0.81\end{array}$ & $\begin{array}{l}0.89 \\
0.79\end{array}$ & $\begin{array}{l}0.99 \\
1.00\end{array}$ & $\begin{array}{l}1.09 \\
1.13 \\
\end{array}$ & $\begin{array}{l}1.88 \\
1.84\end{array}$ & $\begin{array}{l}0.71 \\
0.75 \\
\end{array}$ \\
\hline \multirow{3}{*}{ C } & 無処置 & $\begin{array}{l}1 \\
2\end{array}$ & $\begin{array}{l}\infty \\
\infty\end{array}$ & $\begin{array}{l}\infty \\
\infty\end{array}$ & $\begin{array}{l}5.30 \\
4.25\end{array}$ & $\begin{array}{l}4.12 \\
3.82\end{array}$ & $\begin{array}{l}4.79 \\
4.58\end{array}$ & $\begin{array}{l}4.50 \\
4.22\end{array}$ & $\begin{array}{l}3.80 \\
3.91\end{array}$ \\
\hline & 加 熱 & $\begin{array}{l}1 \\
2\end{array}$ & $\begin{array}{l}0.91 \\
0.96\end{array}$ & $\begin{array}{l}0.88 \\
0.92\end{array}$ & $\begin{array}{l}0.86 \\
0.99\end{array}$ & $\begin{array}{l}0.63 \\
0.73\end{array}$ & $\begin{array}{l}0.75 \\
0.73\end{array}$ & $\begin{array}{l}0.76 \\
0.66\end{array}$ & $\begin{array}{l}0.73 \\
0.59\end{array}$ \\
\hline & Zymosan & $\begin{array}{l}1 \\
2 \\
\end{array}$ & $\begin{array}{r}2.11 \\
2.04 \\
\end{array}$ & $\begin{array}{l}1.18 \\
1.30 \\
\end{array}$ & $\begin{array}{l}1.19 \\
1.54 \\
\end{array}$ & $\begin{array}{l}3.99 \\
3.97 \\
\end{array}$ & $\begin{array}{l}1.57 \\
1.61 \\
\end{array}$ & $\zeta$ & I \\
\hline \multirow{3}{*}{ D } & 無処置 & $\begin{array}{l}1 \\
2 \\
\end{array}$ & $\begin{array}{l}3.03 \\
2.72 \\
\end{array}$ & $\begin{array}{l}3.05 \\
2.86 \\
\end{array}$ & $\begin{array}{l}0.75 \\
0.78 \\
\end{array}$ & $\begin{array}{l}1.28 \\
1.36\end{array}$ & $\begin{array}{l}1.04 \\
0.97 \\
\end{array}$ & $\begin{array}{l}0.46 \\
0.51 \\
\end{array}$ & $\begin{array}{l}0.56 \\
0.57 \\
\end{array}$ \\
\hline & 加 熱 & $\begin{array}{l}1 \\
2\end{array}$ & $\begin{array}{l}0.93 \\
0.87\end{array}$ & $\begin{array}{l}0.54 \\
0.61\end{array}$ & $\begin{array}{l}0.68 \\
0.58\end{array}$ & $\begin{array}{l}1.11 \\
0.84\end{array}$ & $\begin{array}{l}1.02 \\
0.89 \\
\end{array}$ & $\begin{array}{l}0.51 \\
0.59 \\
\end{array}$ & $\begin{array}{l}0.60 \\
0.69 \\
\end{array}$ \\
\hline & Zymosan & $\begin{array}{l}1 \\
2\end{array}$ & $\begin{array}{l}0.90 \\
0.82\end{array}$ & $\begin{array}{l}0.62 \\
0.54\end{array}$ & $\begin{array}{l}0.76 \\
0.68\end{array}$ & I & 7 & ノ & ノ \\
\hline \multirow{3}{*}{$\mathrm{E}$} & 無処置 & $\begin{array}{l}1 \\
2 \\
\end{array}$ & $\begin{array}{l}3.74 \\
3.55\end{array}$ & $\begin{array}{l}3.29 \\
3.31 \\
\end{array}$ & $\begin{array}{l}1.44 \\
1.26 \\
\end{array}$ & $\begin{array}{l}2.76 \\
2.72 \\
\end{array}$ & $\begin{array}{l}1.07 \\
0.97 \\
\end{array}$ & $\begin{array}{l}1.64 \\
1.64 \\
\end{array}$ & $\begin{array}{l}1.10 \\
1.13 \\
\end{array}$ \\
\hline & 加 熱 & $\begin{array}{l}1 \\
2\end{array}$ & $\begin{array}{l}0.79 \\
0.73\end{array}$ & $\begin{array}{l}0.77 \\
0.94\end{array}$ & $\begin{array}{l}0.79 \\
0.88 \\
\end{array}$ & $\begin{array}{l}1.26 \\
1.07\end{array}$ & $\begin{array}{l}0.92 \\
0.85 \\
\end{array}$ & $\begin{array}{l}0.78 \\
0.76 \\
\end{array}$ & $\begin{array}{l}0.83 \\
0.88 \\
\end{array}$ \\
\hline & Zymosan & $\begin{array}{l}1 \\
2\end{array}$ & $\begin{array}{l}1.05 \\
1.03 \\
\end{array}$ & I & I & I & I & 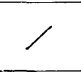 & l \\
\hline \multirow{3}{*}{ F } & 無処置 & $\begin{array}{l}1 \\
2\end{array}$ & $\begin{array}{l}3.84 \\
3.90\end{array}$ & $\begin{array}{l}3.85 \\
4.22\end{array}$ & $\begin{array}{l}2.01 \\
2.05\end{array}$ & $\begin{array}{l}2.80 \\
2.64\end{array}$ & $\begin{array}{l}1.35 \\
2.01 \\
\end{array}$ & $\begin{array}{l}2.55 \\
2.40 \\
\end{array}$ & $\begin{array}{l}0.91 \\
0.94\end{array}$ \\
\hline & 加 熱 & $\begin{array}{l}1 \\
2\end{array}$ & $\begin{array}{l}1.03 \\
1.00\end{array}$ & $\begin{array}{l}1.12 \\
1.14\end{array}$ & $\begin{array}{l}1.33 \\
1.01\end{array}$ & $\begin{array}{l}1.08 \\
0.96\end{array}$ & $\begin{array}{l}1.49 \\
1.37 \\
\end{array}$ & $\begin{array}{l}0.79 \\
0.73 \\
\end{array}$ & $\begin{array}{l}0.90 \\
0.84 \\
\end{array}$ \\
\hline & Zymosan & $\begin{array}{l}1 \\
2\end{array}$ & I & I & I & I & 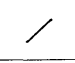 & I & I \\
\hline
\end{tabular}

の10日後においても菌を検出できたかつたもの

は血液の lotによつて著しく開きがあり，血液 と血漿との間にも差がある（表 3 , 図 5 ). 血液の 殺菌扎 lot によつて異なるが，かならずしも 急速に低下するものではなく，3 週間後も殆んど 殺菌力の低下が詳められない例もあつた。一方血 漿の殺菌力は，大部分が 3 週間後に殆んど失なわ れるが，完全には失なわれない例もあつた。血 液，血漿の殺菌力の低下を同一 1ot 間で比較し てみると，常に血液より血漿で呆存された試料の 方が低下速度がはやく，この逆の場合は 1 例もな
かつた。

加熱血漿を殺菌力の完全に失なわれた対照と考 えこれを基準にして血液及び血漿の保存別に殺 菌力低下の程度を各週毎に lot 数で比較してみて も血嶈より血液のま〉保された場合の方が低下率 が小さいことがわかる。

以上のことから血漿で保存された場合よりも， 全血液の状態で保存された方が一般に殺菌力は安 定であることをしることができた。

なお保存後も残存する $37^{\circ}$ で発揮する殺菌作用 
図 54 ～60 保存による血液及び血漿の L 指数 の変化 Lot. A

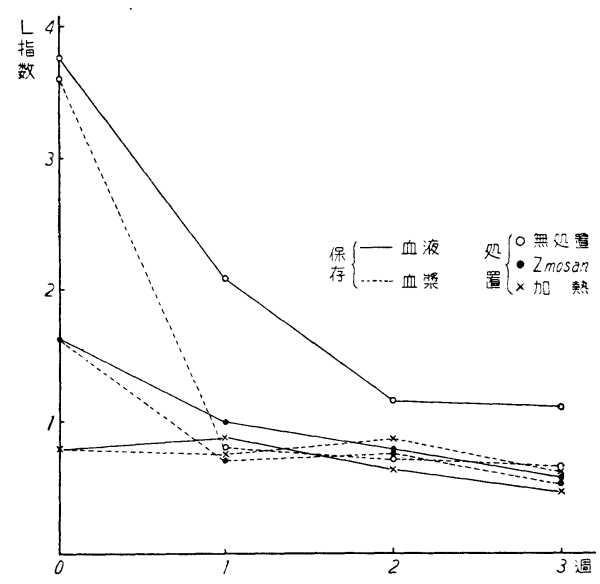

は zymosan 及び $56^{\circ} 30$ 分加熱の 各処置によつ て減弱され，その減弱の程度から若えて採血直後 に示される殺菌作用の性状と同一のものと考えら れる。

小括

新鮮保存血液, 血漿の $37^{\circ}$ でみられる殺菌作用 が同一であることを確かめることができたので, この血液殺菌作用の本態が血漿部にあるものと考 えこれが properdin system によるものでは なからうかとの推定から，血漿につき zymosan を用いて実験した結果，殺菌作用が zymosan に よつて不活化されることがわかつた。

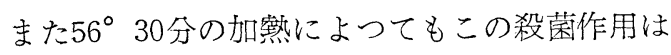
不活化される。これらの事実は，血液の $37^{\circ}$ でみ られる殺菌作用が properdin system によるも のとする推定に背馳しないが，これを積極的に肯 定するためにはまた実験が不足していると考えら れる。

なお，血液，血漿の保存による殺菌作用の変 化についてしらべた結果，血液で保存した方が血 漿で保存した場合よりも安定であることがわかつ $た$.

以上の殺菌作用の性状に関する美験は，この実 験を通じて，第I部で提案した推測一表現方法の 有效性についての検討をも同時に行なわれた実験 であるが，はじめに述へたこの方法は，実験手技
の点で改良しなければならない部分もあるが，得 られた笑験結果から考えてこの方法の理論的根拠 の有意性を確証することができ，また案際にも有 効であると考えられた。

\section{総括並びに結論}

保存血液の $37^{\circ}$ で発揮される殺菌作用の力価を 定量的にあらわす新らしい方法について実験検討 した.その結果, 殺菌作用後の試料を $4 \sim 6^{\circ}$ に 移して培養するとき, 試料中の生残菌の対数殖増 直線と同一実験操作で行なわれたブイヨンでの菌 のそれとがほぼ平行であり，またブイヨンでの対 数増殖直線の位置が注一定していること, 初発 菌数の割合と対数増殖直線の立置の開きが注济平 行していることが実験的に確かめられた。これら の事実を応用して，ブイヨンでの坟数増殖直線を 標準にとり，これと被検試料での対数増殖直線の 位置との開きを相対力価の一般式によつて計算し てその差を日数であらわし（几指数と名づけた）, これをもつて被検試料の殺菌作用の力価を表現す る方法を考案した。

次にこの方法を実際に応用して血液の殺菌作用 の性状一機構に関する諸実験を行い，その結果か ら私の考案した血液殺菌力の推測一表現方法が有 効であることを確認した。

またここれらの実験を通じて，保存血液の細菌 质染に重要な関係をもつグラム侩性低温発育菌の 血液中での増殖に関し，いくつかの新らしい知見 を得ることができた。

稿を終るに臨み, 終指悶篤な御指導御䩿撻御校閲を 賜つた順天堂医科大学 土屋毅教授, 国立予防衛生研 所 黑川正身博士並ぶに市川洋一博士に対しして深甚 な究る謝意を表する. 又推計学的処理で協力いたぶい た石田説而氏に謝意を表する。

(本研究は厚生科学研究費の援助によつたことを附記 する).

\section{文 献}

1) Arday, F.R., Pillemer, L. \& Lepow, I.H.: The properdin system and immunity: VIII. Studies on the purification and properties of the third component of human complement. J. Immunol., 82 : 458, 1959. 
2) Borden, C.W. \& Hall, W.H.: Fatal transfusion reactions from massive bacterial contamination of blood. New England J. Med., 245 : 766, 1951.

3) Finny, M.A.: Statistical Method in Biological Assay. 1952. Charls Griffin. London.

4) Geller, P., Chandler, L. \& Jawetz, E.: Experimental studies on bacterial contamination of bank blood: III. The survival and growth of bacteria in bank blood incubated at $37 \mathrm{C}$. for short periods before refrigeration. J. Lab. \& Clin. Med., 49: 573, 1957.

5) Isliker, H.C.: The properdin system, a review. Vox Sang., I : 8, 1956.

6) 厚生省 : 生物学的製剤基準, 1959 .

7) 森口繁一：統計解析, 1957, 岩波書店.

8) Pittman, M.: A study of bacteria implicated in transfusion reactions and of bacteria isolated from blood products. J. Lab. \& Clin. Med., 42. 273, 1953.

9) Pillemer, L., Blum L., Lepow, I.H., Ross,
O.A., Todd, E.W. \& Wardlaw, A.C.: The properdin system and immunity: I. Demonstration and isolation of a new serum protein, properdin, and its role in immune phenomena. Science, $120: 279,1954$.

10) Pillemer, L., Blum L., Lepow, I.H., Wurz, L. \& Todd, E.W.: The properdin system and immunity: III. The zymosan assay of properdin. J. Exp. Med., 103 : 1, 1956.

11) Wardlaw, A.C. \& Pillemer, L.: The properdin system and immunity: V. The bactericidal activity of the properdin system. J. Exp. Med., 103 : 553, 1956.

12）山口晴一 (斎藤), 尾崎順一, 市川洋一：保存 血の細菌污染防止に関する研究（第 2 報）：保 存血の温度変化々污染菌の消長 $(1)$, 第 6 回 日本輸血学会総会誌 (血液と輸血), $4: 246$, 1958.

13）山口晴一 (斎藤), 市川洋一：保存血の細菌污 染防止に関する研究（第 3 報）：保存血の盜 度変化と污染細菌の消長 ( 2 ), 第 7 回日本輸 血学会総会誌(日本輸血学会雑誌), 5: 235, 1959. 